\title{
PROGRAM DOKTOR MENGABDI DIVERSIFIKASI PRODUK OLAHAN BERBASIS MANGROVE DI DESA BANYUURIP KECAMATAN UJUNG PANGKAH KABUPATEN GRESIK JAWATIMUR
}

\author{
Muhammad Arif Rahman ${ }^{1,3}$, Defri Yona ${ }^{1,3}$, Nurin Hidayati ${ }^{1,3}$, Syarifah Hikmah Julinda Sari ${ }^{1,3}$, Iis \\ Nur Rodliyah ${ }^{2}$

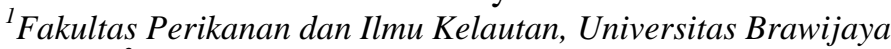 \\ ${ }^{2}$ Fakultas Ilmu Budaya, Universitas Brawijaya \\ ${ }^{2}$ Marine Research Exploration and Management (MEXMA) Research Group, Universitas Brawijaya Jalan \\ Veteran Malang 65145 \\ * email:arifelzain@ub.ac.id
}

\begin{abstract}
Sejak tahun 2013, Pemerintah Desa Banyuurip bersama dengan Kelompok Pelestari Mangrove dan Lingkungan Banyuurip mendirikan Kawasan Ekowisata dan Konservasi Mangrove yang dikenal dengan nama Banyuurip Mangrove Center (BMC). Selain sebagai tempat pembibitan dan pelestarian mangrove, kawasan ekowisata yang mulai dibuka pada tahun 2015 ini memiliki berbagai jenis mangrove dengan jenis yang mendominasi adalah Avicennia sp. dan Rhizophora. Saat buah mangrove melimpah, penduduk sekitar BMC kadang memanfaatkannya sebagai olahan seperti sirup dan jenang untuk dikonsumsi sendiri. Berangkat dari permasalahan ini, Program Doktor Mengabdi Universitas Brawijaya Tahun 2018 dilakukan untuk membantu para pengelola ekowisata mangrove dalam memanfaatkan dan mengelola produk-produk mangrove untuk mengembangkan ekowisata mangrove yang telah berjalan. Kegiatan yang dilakukan untuk mengatasi masalah tersebut adalah dengan mengadakan pelatihan pengolahan produk mangrove oleh praktisi dari Lamongan yang telah sukses mengolah kopi mangrove serta tim dari KeSEMaT, Semarang yang telah memiliki banyak desa binaan dengan berbagai macam produk seperti stik mangrove, krupuk mangrove, cendol mangrove serta batik mangrove. Dengan adanya pemanfaatan dan pengelolaan produk mangrove, maka BMC diharapkan dapat menjadi satu paket tempat wisata yang lengkap, yakni wisata alam, wisata pendidikan, dan juga wisata ekonomi.
\end{abstract}

\section{Kata Kunci : BMC, Mangrove Jawa Timur, Produk Mangrove}

\section{PENDAHULUAN}

Hutan mangrove merupakan suatu kawasan yang memiliki fungsi ekologis dan ekonomis yang tinggi bagi kehidupan di wilayah pesisir. Mangrove yang biasanya tumbuh diantara lingkungan darat dan laut juga merupakan salah satu ekosistem yang sangat produktif (Noor et al., 2006). Sejak lama, manusia telah memanfaatkan hutan mangrove dalam keseharian mereka misalnya dengan mengambil atau menebang pohon mangrove untuk bahan bakar, bahan bangunan, dan bahan pembuatan perahu (Herwanti, 2015; Sahil dan Soamole, 2013). Hal ini disinyalir menjadi salah satu penyebab penurunan kawasan hutan mangrove secara global.

Padahal, selain pemanfaatan mangrove secara destruktif (penebangan), bagian mangrove, terutama buahnya, juga dapat dimanfaatkan sebagai salah satu sumber pangan alternative. Buah mangrove yang telah diolah menjadi tepung memiliki kandungan serat $(35,4 \%)$, protein $(17 \%)$, lemak $(14 \%)$, air $(11,8 \%)$, abu $(1,2 \%)$, serta antioksidan yang cukup tinggi dan mampu menangkal radikal bebas hingga $71 \%$ (A'in et al., 2017). Tepung mangrove tersebut dapat diolah menjadi berbagai macam produk seperti cendol, krupuk, kue, dan stick. Selain menjadi tepung, buah mangrove juga dapat diolah menjadi minuman seperti sirup (A'in et al., 2017; Subekti, 2012; Sabana, 2014; Herwanti, 2015).

Desa Banyuurip, Kecamatan Ujungpangkah, Kabupaten Gresik, Jawa Timur merupakan salah satu desa yang memiliki potensi mangrove. Sempat mengalami kerusakan akibat abrasi dan aktifitas manusia yang kurang bertanggung jawab, masyarakat desa mulai sadar akan pentingnya mangrove dan membentuk Banyuurip Mangrove Center (BMC) sebagai tempat pembibitan dan pembelajaran mangrove serta tanaman pantai lainnya. Saat ini, sekitar 47.500 bibit mangrove mampu dihasilkan oleh BMC untuk ditanam di sekitar area desa Banyuurip ataupun dijual ke luar desa (Yona et al., 2017).

Universitas Brawijaya (UB) Malang melalui program Doktor Mengabdi (DM) mulai masuk dan ikut serta dalam pengelolaan BMC sejak tahun 2017. Pada tahun ini, hal yang menjadi fokus utama adalah melengkapi fungsi BMC sebagai tempat pembelajaran mangrove, dengan membangun ruang baca atau perpustakaan seluas $25 \mathrm{~m}^{2}$ di area BMC. Ruang baca ini dilengkapi dengan buku, poster serta leaflet tentang mangrove, dengan harapan masyarakat sekitar maupun wisatawan yang berkunjung ke BMC akan lebih banyak tahu tentang 
mangrove serta tumbuh kepedulian terhadap mangrove sepulang dari BMC.

Tahun 2018, tim DM UB kembali ke BMC dengan fokus pemanfaatan mangrove sebagai produk makanan dan minuman dengan tujuan untuk memberikan informasi dan keterampilan dalam mengolah produk mangrove kepada pengelola dan masyarakat sekitar BMC. Sehingga pada akhirnya, mereka mampu memanfaatkan bagian-bagian mangrove menjadi makanan dan minuman yang dapat dipasarkan di sekitar BMC.

Mekipun pemanfaatan buah mangrove telah dilakukan di beberapa lokasi, pengetahuan tentang produk dan cara pengolahan makanan serta minuman berbahan dasar mangrove masih belum terlalu banyak diketahui oleh publik, meskipun mereka berada disekitar kawasan hutan mangrove (A'in et al., 2017; Baderan, et al., 2015; Sahil dan Soamole, 2013). Hal serupa juga terjadi pada masyarakat sekitar BMC. Pada saat buah mangrove melimpah, beberapa orang mengolah bahan tersebut menjadi sirup dan jenang untuk konsumsi pribadi, namun masih banyak buah yang dibiarkan jatuh disekitar mangrove dan tidak termanfaatkan.

\section{METODE}

Program DM UB ini dilaksanakan mulai Juli sampai September 2018. Pada rentang waktu tersebut dilakukan beberapa kegiatan dan pelatihan. Pelatihan dilakukan dengan metode ceramah, dimana peserta mendapatkan teori dasar tentang pengolahan produk makanan dan minuman berbahan dasar mangrove. Selain itu, metode lain yang digunakan adalah praktik, dimana peserta diberikan kesempatan untuk ikut serta berpartisipasi dalam pembuatan produk mangrove dengan didampingi oleh pemateri.

\section{HASIL DAN PELAKSAAN PROGRAM}

Terdapat 2 (dua) kegiatan utama dan beberapa kegiatan lainnya yang dihasilkan dari program DM UB dengan luaran yang dapat dirasakan tidak hanya oleh pihak desa mitra, tetapi juga oleh pihak UB sendiri.

\section{Sosialisasi dan Focus Group Discussion (FGD)}

Kegiatan yang dilaksanakan pada bulan Juli 2018 ini menitik beratkan pada penyampaian rencana kegiatan yang akan dilakukan oleh tim DM UB tahun 2018. Selain itu, kegiatan yang dihadiri oleh perangkat desa Banyuurip, perwakilan karang taruna, serta nelayan pengelola BMC ini dilanjutkan dengan melakukan FGD. Kegiatan ini ditujukan untuk mendapatkan masukan dari peserta tentang kegiatan yang telah dilakukan di tahun 2017, serta kegiatan yang mereka perlukan dan inginkan untuk dilaksanakan pada tahun 2018. Masukan dari peserta FGD kemudian dijadikan bahan oleh tim DM UB untuk menentukan pelatihan yang akan diberikan.

\section{Pelatihan Pengolahan Produk Berbahan Dasar Mangrove}

Kegiatan ini merupakan kegiatan utama dalam program DM 2018. Pelatihan yang dilaksanakan pada akhir bulan September 2018 ini dihadiri oleh perwakilan ibu-ibu PKK desa Banyuurip, karang taruna, dan pengelola BMC. Praktisi yang didatangkan untuk memberikan pelatihan berasal dari 2 (dua) tempat yang berbeda. Pemateri pertama adalah pemilik Kedai Kopi Brayo, Lamongan yang sukses mengolah kopi dengan memasukkan bahan mangrove didalamnya. Proses pembuatan kopi mangrove dapat memakan waktu lebih dari 3 (tiga) hari, oleh karena itu pemateri telah mempersiapkan bubuk kopi mangrove terlebih dahulu (Gambar 1) sedangkan materi tentang pembuatannya disampaikan dalam sesi ceramah. Proses pembuatan kopi ini dilakukan dalam beberapa tahapan:

1. Siapkan biji kopi excelsa dan buah mangrove Rhizophora sp. yang telah dipotong kecil-kecil. Perbandingan antara buah mangrove dan biji kopi adalah 1:2 (500 g buah mangrove untuk $1 \mathrm{~kg}$ biji kopi).

2. Cuci buah mangrove hingga bersih, tiriskan, kemudian masukkan kedalam termos berisi 1 liter air bersih.

3. Bungkus biji kopi menggunakan kain bersih, kemudian masukkan kedalam termos, tutup rapat, dan biarkan selama 18 jam.

4. Pisahkan biji kopi dengan buah mangrove, bilas hingga bersih, lalu tiriskan.

5. Jemur biji kopi selama 5 (lima) jam untuk hari pertama, 4 (empat) jam untuk hari kedua, dan 3 (tiga) jam untuk hari berikutnya hingga kering sempurna.

6. Sangrai biji kopi dan buah mangrove secara terpisah.

7. Giling dengan grinder / blender.

8. Kopi mangrove siap diseduh.

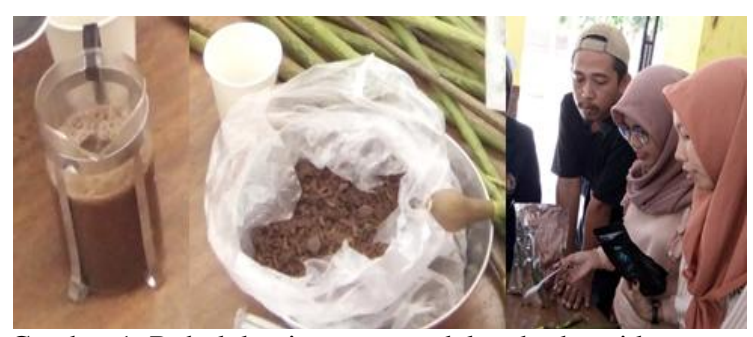

Gambar 1. Bubuk kopi mangrove dalam berbagai kemasan

Peserta yang hadir, terutama dari perwakilan karang taruna dan pengelola BMC memberi komentar bahwa rasa kopi mangrove ini unik karena ada aroma mangrove didalamnya. Mereka yakin, 
kedepannya kopi mangrove ini dapat menjadi salah satu favorit pengumjung BMC apabila telah dipasarkan.

Materi kedua adalah tentang pembuatan tepung mangrove yang nantinya dapat dimanfaatkan untuk membuat berbagai macam produk. Dalam pelatihan ini, produk yang dibuat adalah es cendol. Pemateri didatangkan dari Kelompok Studi Ekosistem Mangrove Teluk Awur (KeSEMaT), Universitas Diponegoro, Semarang, yang memiliki banyak desa binaan dan sukses membuat berbagai macam produk seperti krupuk mangrove, stik mangrove, sampai batik mangrove.

Kegiatan dimulai dengan pembuatan tepung (Gambar 2) sebagai bahan dasar pembuatan cendol. Sama seperti kopi mangrove, dikarenakan proses perebusan mangrove memakan waktu 3 (tiga) hari, maka pemateri telah mempersiapkan rebusan buah mangrove untuk kegiatan pelatihan. Sementara itu, proses lengkap pembuatan tepung mangrove disajikan dalam sesi ceramah. Tepung mangrove dapat dibuat dari Brugueira sp. maupun Avicennia $s p$. , dalam materi disampaikan proses pembuatan tepung mangrove dari jenis Avicennia marina. Proses pembuatan tepung mangrove melalui beberapa tahapan:

1. Kupas daging buah mangrove dari kulitnya, diikuti dengan pemisahan lembaga dari putiknya.

2. Masukkan buah mangrove kedalam air mendidih selama 10 menit.

3. Rebus kembali mangrove dengan menambahkan abu gosok selama 30 menit.

4. Cuci buah mangrove sampai bersih.

5. Rendam buah mangrove selama $3 \times 24$ jam. Lakukan penggatian air rendaman setiap 8 jam.

6. Setelah ditiriskan, haluskan buah mangrove dengan menumbuk atau menggunakan blender.

7. Tuang halusan buah mangrove keatas karung plastik atau alas yang bersih hingga rata dan usahakan agar setipis mungkin.

8. Jemur dibawah terik matahari hingga kering.

9. Kumpulkan dan haluskan sekali lagi dengan blender.

10. Tepung mangrove selesai dibuat.

Setelah selesai, tepung mangrove yang telah halus dapat diolah menjadi berbagai macam produk makanan dan minuman dengan menambahkan bahan-bahan sesuai kebutuhan.

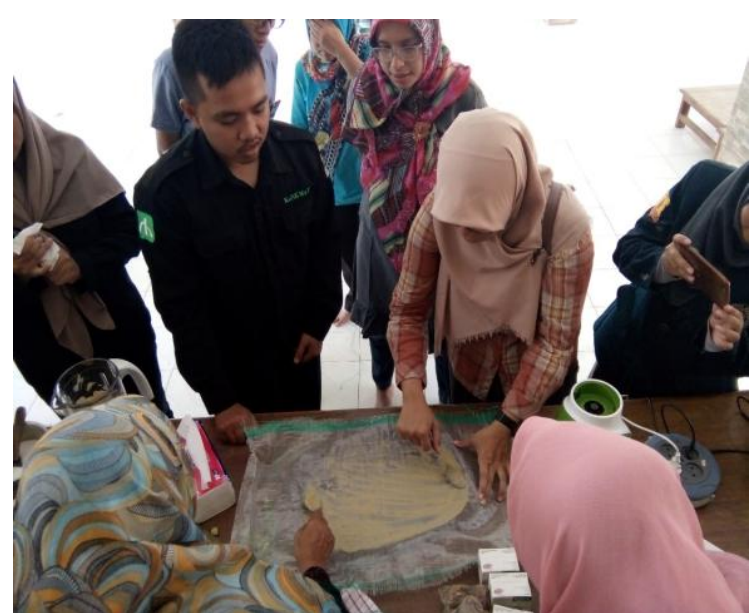

Gambar 2. Adonan tepung mangrove yang akan dijemur

Pelatihan pembuatan produk berbahan dasar mangrove yang telah diterima oleh perwakilan masyarakat desa Banyuurip memberikan hasil yang positif. Akhir bulan Oktober, tim DM UB bersama reviewer kembali ke desa Banyuurip dalam rangka monitoring dan evaluasi berjalannya program DM UB. Salah satu hal yang disajikan oleh masyarakat desa Banyuurip adalah makanan ringan berbahan dasar mangrove seperti stik mangrove dan puding mangrove. Selain itu, terdapat pula hasil olahan masyarakat yang mengkombinasikan antara tepung mangrove dengan bahan lain yang ada disekitar BMC seperti kupang dan daun acanthus (Gambar 3).

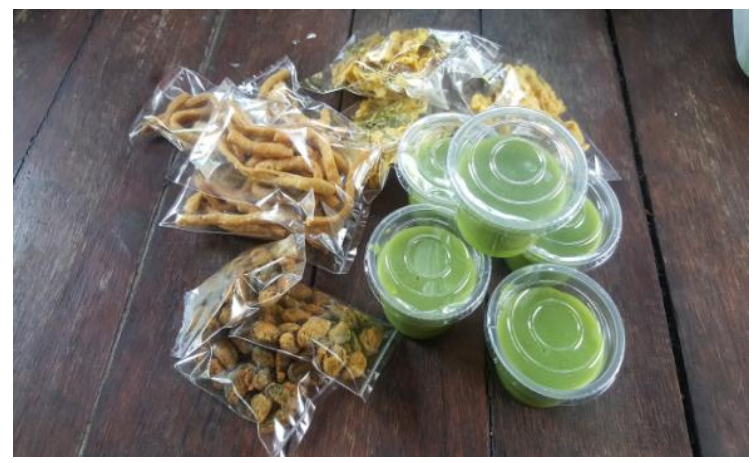

Gambar 3. Produk makanan ringan berbahan dasar mangrove buatan masyarakat desa Banyuurip

Hal ini memberikan harapan bahwa kedepannya, produk makanan dan minuman berbahan dasar mangrove dapat diproduksi dan dipasarkan di sekitar BMC. Sehingga, harapan agar dikemudian hari BMC dapat menjadi satu paket tempat wisata yang lengkap, yakni wisata alam, wisata pendidikan, dan juga wisata ekonomi dapat tercapai.

\section{Pelibatan Mahasiswa dalam Pengelolaan BMC}

Selain melibatkan diri dalam mendukung pengembangan dan pengelolaan BMC, program DM UB juga turut serta membantu mengembangkan jejaring UB dengan masyarakat luas. Sebagai salah 
satu timbal balik yang didapatkan oleh UB adalah pemerintah desa Banyuurip membuka diri bagi mahasiswa UB yang akan melakukan penelitian maupun magang di kawasan BMC. Sampai saat ini, beberapa topik tentang hutan mangrove dan kondisi lingkungannya telah diambil oleh mahasiswa sebagai bahan penelitian maupun magang mereka. Hasil penelitian tersebut dapat dijadikan sebagai salah satu masukan dalam pengembangan pengelolaan BMC kedepannya.

\section{KESIMPULAN}

Program DM UB ini dilakukan untuk meningkatkan fungsi BMC sebagai sentra edukasi dan ekonomi terkait mangrove. Pelatihan pengolahan produk mangrove yang dilakukan dengan mengundang praktisi olahan produk mangrove, telah dirasakan dapat memberikan manfaat bagi masyarakat desa Banyuurip, sehingga mereka dapat mengembangkan olahan produk mangrove. Produk-produk ini selanjutnya diharapkan dapat dipasarkan sebagai salah satu keunggulan desa Banyuurip dan oleh-oleh khas BMC.

\section{UCAPAN TERIMAKASIH}

Kegiatan ini terlaksana dengan biaya dari Program Doktor Mengabdi Universitas Brawijaya tahun 2018. Terimakasih kami ucapkan kepada Kepala Desa Banyuurip dan Bapak Abdul Mughni atas ijin dan bantuannya sehingga kegiatan ini dapat terlaksana dengan baik.

\section{DAFTAR PUSTAKA}

[1] A'in, C., Suryanti, dan Sulardiono, B. 2017. Kandungan Gizi pada Produk Olahan Mangrove (KruMang, BoMang, dan SiMang) Produksi Kelompok Tani "Ngudi Makaryo". Jurnal INFO. 19 (1). 24-33

[2]Baderan, D.W.K., Hamidun, M.S., Lamangandjo, C., dan Retnowati, Y. 2015. Diversifikasi Produk Olahan Buah Mangrove Sebagai Sumber Pangan Alternatif Masyarakat Pesisir Toroseaje Kabupaten Pohuwato Provinsi Gorontalo. Prosiding Seminar Nasional Masyarakat Biodiversity Indonesia. Gorontalo

[3] Herwanti, S. 2015. Kajian Pengembangan Usaha Sirup Mangrove di Desa Margasari Kecamatan Labuhan Maringgai Kabupaten Lampung Timur. Jurnal Hutan Tropis. 4 (1). 35-40

[4 Noor, Y.R., Khazali, M., dan Suryadiputra, I.N.N. 2006. Panduan Pengenalan Mangrove di Indonesia. Wetlands International Indonesia Programme. Bogor

[5] Sabana, C. 2014. Kajian Pengembangan Produk Makanan Olahan Mangrove. Jurnal Ekonomi dan Bisnis. 14 (1). 40-46

[6] Sahil, J., dan Soamole, I. 2013. Pemanfaatan Buah Mangrove Sebagai Sumber Makanan Alternatif di Halmahera Barat, Maluku Utara. Biogenesis. 1 (2). 91-96
[7] Subekti, S. 2012. Pengelolaan Mangrove Sebagai Salah Satu Keanekaragaman Bahan Pangan. Prosiding SNST ke-3. Semarang

[8] Yona, D., Hidayati, N., Sari, S.H.J., Amar, I.N., dan Sesanty, K.W. 2018. Teknik Pembibitan dan Penanaman Mangrove di Banyuurip Mangrove Center Desa Banyuurip Kecamatan Ujungangkah Kabupaten Gresik. J-Dinamika. 3 (1). 67-70 